\title{
Growth performance and nutrient digestibility of weaner pigs fed cereal offals in diets \\ ${ }^{*}$ Wafar, R. J., ${ }^{2}$ Tarimbuka, L. I, ${ }^{3}$ Sini, T., ${ }^{1}$ Adi, Z. A., ${ }^{1}$ Lamalang, E. B. and ${ }^{1}$ Bako, M. I. ${ }^{\prime}$ Department of Animal Production and Health, Federal University Wukari, PMB 1020 Wukari Taraba State ${ }^{2}$ Department of Animal Health and Production Technology, Adamawa State College of Agriculture, Ganye, Nigeria. \\ ${ }^{3}$ Department of Agriculture Education, Adamawa State College of Education, Hong Adamawa State \\ *Corresponding author: rjwafari@gmail.com; +2348066320686 \\ Abstract
}

Thirty (30) weaned crossbred (Landrace $\times$ large white) pigs with an average body weight of $8.5 \pm 0.4 \mathrm{~kg}$ was used to evaluate performance and nutrient digestibility of weaned pigs fed five experimental diets containing cereal milling by-products. Diet 1 contained maize offal, while diets 2, 3, 4 and 5 contained wheat offal, sorghum offal, millet offal and rice offal respectively. The animals were balanced for sex and weight then allotted to five dietary treatments replicated three times in a completely randomized design. Data were collected on feed intake and weight gain for a period of eight weeks. A digestibility trial was carried at the end of the feeding trial using three pigs per treatment. Data collected were subjected to oneway analysis of variance. The result of growth performance and nutrient digestibility showed that average feed intake, final body weight as well as digestibility of dry matter, crude fibre, ether extracts, crude protein and ash were higher $(P<0.05)$ for pigs fed T1 (maize offal), T2 (wheat offal), T3 (sorghum offal) and T4 (millet offal), while those on T5 (Rice offal) had the lowest growth and nutrient digestibility. It was concluded that maize offal, wheat offal, sorghum offal, millet offal can be used in weaner pigs' diet.

Keywords: Digestibility, growth performance, offal, pigs

\section{La Performance de croissance et la digestibilité des éléments nutritifs des porcs sevrés nourris avec desaliments de céréales dans l'alimentation}

\section{Résumé}

Trente (30) porcs croisés sevrés (Landrace $\times$ Large white) d'un poids corporel moyen de 8,5 $\pm 0,4 \mathrm{~kg}$ ont été utilisés pour évaluer les performances et la digestibilité des nutriments de porcs sevrés nourris avec cinq régimes expérimentaux contenant des sous-produits de la mouture de céréales. Le régime 1 contenait des as des aliments de maïs, tandis que les régimes 2, 3, 4 et 5 contenaient respectivement des aliments de blé, des aliments de sorgho, des aliments de mil et des aliments de riz. Les animaux ont été équilibrés pour le sexe et le poids puis attribués à cinq traitements diététiques répétés trois fois dans une conception complètement aléatoire. Des données ont été recueillies sur la prise alimentaire et la prise de poids pendant une période de huit semaines. Un essai de digestibilité a été réalisé à la fin de test d'alimentation en utilisant trois porcs par traitement. Les données collectées ont été soumises à une analyse unidirectionnelle de la variance. Le résultat des performances de croissance et de la digestibilité des nutriments a montré que l'apport alimentaire moyen, le 


\section{Growth performance and nutrient digestibility of weaner pigs fed cereal offals in diets}

poids corporel final ainsi que la digestibilité de la matière sèche, des fibres brutes, des extraits d'éther, des protéines brutes et des cendres étaient plus élevés $(P<0,05)$ pour les porcs nourris au T1 (aliments de maïs). , T2 (aliments de blé), T3 (aliments de sorgho) et T4 (aliments de millet), tandis que ceux de T5 (aliments de riz) avaient la plus faible croissance et digestibilité des éléments nutritifs. Il a été conclu que les aliments de maïs, les aliments de blé, les aliments de sorgho, les aliments de millet peut être utilisé dans l'alimentation des porcs sevrés.

Mots clés : digestibilité, performances de croissance, abats, porcs

\section{Introduction}

High cost of feeding has been identified as one the major impeding factors affecting the pig industry in developing countries (Uddin and Osasogie, 2016). This is as a result of continued increase in prices of conventional feedstuffs which are mostly used as sources of dietary energy and protein. However, for the pig industry to remain profitable, development of lowcost feeding strategies which are locally available to pig farmers has been the major challenge of animal nutritionist (Nelson et al. 2007). The use of agro-based byproducts in pigs has been evaluated by various researchers indicating improved growth performance (De Lange et al., 2010; Kim et al., 2011) while others reported depressed performances and poor nutrient absorption (De la Llata et al., 2001) due to high dietary fibre which depends on the cereal type (Freira et al., 2000; Galassi et al., 2004), type and extent of milling (Amaefule et al. 2009) as well as climate and soil conditions where the grain is produced (Wenk 2001). The comparative evaluation of feeding cereal milling byproducts on pig performance and nutrient digestibility is scanty. This study therefore assessed the performance and nutrient digestibility of weaned pigs fed diets containing cereal milling by-products.

\section{Materials and methods Study site}

The study was carried out in a Shapwo farms a private Piggery farm located at
Numan, Adamawa. The study area lies between Latitude $9^{\circ} 22^{\prime}$ North of the Equator and Longitude $12^{\circ} 2^{\prime}$ East and has a tropical wet and dry climate with relative humidity that ranges from 5 to $32 \%$ and average maximum temperature of $32^{\circ} \mathrm{C}$ (Adebayo, 1999).

\section{Experimental diets}

Five experimental diets (Table 1) were formulated based on the five cereal milling by-products i.e. maize offal, wheat offal, sorghum offal, and millet offal and rice bran. The test ingredients were purchased at the agro-by product market in Yola. Diet 1 contained maize offal, while diets 2, 3, 4 and 5 contained wheat bran sorghum offal, millet offal and rice bran

\section{Experimental animals, management and design}

Thirty crossbred (Landrace $\times$ Large white) pigs with an average initial body weight of $8.00 \pm 0.56 \mathrm{~kg}$ were used for the experiment. The animals were randomly allotted to five dietary treatment groups replicated three (3) times in a completely randomized design (CRD) with two pigs per replicate. Each replicate was housed in pen constructed with solid concrete floor fitted with water and feeding troughs. The pigs were offered experimental diets throughout the period of the experiment.

\section{Data collection}

\section{Growth parameters}

Pigs were weighed at the beginning of the experiment and weekly, subsequently. Weight gain was calculated as final live body weight minus initial live body weight. 
Feed intake was obtained as the difference between the quantity offered and quantity not consumed. Feed conversion ratio (FCR) was calculated as feed intake divided by weight gain

\section{Digestibility study}

At the $8^{\text {th }}$ week of the experiment, fecal sample was collected from each replicate for 5 successive days at an interval of 24 hours. The feces were placed on aluminum plate to ease drying under the sun. Representative of the fecal samples were analyzed for proximate composition according to AOAC, (2000). Nutrient digestibility was calculated thus:
Nutrient digestibility $=$

Nutrient intake-nutrient in feces $\quad$ x 100

Nutrient intake

\section{Chemical analyses}

The crude protein and fibre contents of cereal milling by products and proximate composition of faeces were determined using the analytical methods described by AOAC, (2000).

Statistical analysis

Data collected were subjected to one-way analysis of variance using SAS (2003) means were separated using Duncan's Multiple Range Test of same software.

Table 1: Ingredient and Percentage Composition of Experimental Diets

\begin{tabular}{llllll}
\hline \multirow{2}{*}{ Ingredient } & \multicolumn{5}{c}{ Dietary treatments } \\
\cline { 2 - 6 } Maize offal & T1 & T2 & T3 & T4 & T5 \\
Millet offal & 56.00 & 0.00 & 0.00 & 0.00 & 0.00 \\
Sorghum offal & 0.00 & 56.00 & 0.00 & 0.00 & 0.00 \\
Wheat offal & 0.00 & 0.00 & 56.00 & 0.00 & 0.00 \\
Rice offal & 0.00 & 0.00 & 0.00 & 56.00 & 0.00 \\
Soybean cake & 0.00 & 0.00 & 0.00 & 0.00 & 56.00 \\
Kapok seed cake & 20.00 & 20.00 & 20.00 & 20.00 & 20.00 \\
Fishmeal & 10.00 & 10.00 & 10.00 & 10.00 & 10.00 \\
Bone meal & 10.00 & 10.00 & 10.00 & 10.00 & 10.00 \\
Methionine & 2.00 & 2.00 & 2.00 & 2.00 & 2.00 \\
Lysine & 0.50 & 0.50 & 0.50 & 0.50 & 0.50 \\
Salt & 0.50 & 0.50 & 0.50 & 0.50 & 0.50 \\
Premix & 0.50 & 0.50 & 0.50 & 0.50 & 0.50 \\
Total & 0.50 & 0.50 & 0.50 & 0.50 & 0.50 \\
Determined analysis & 100 & 100 & 100 & 100 & 100 \\
ME/Kcal/kg & 2727.91 & 2701.56 & 2768.89 & 2834.56 & 2714.56 \\
Crude protein & 20.79 & 20.12 & 20.89 & 20.89 & 20.10 \\
Crude fibre & 16.45 & 17.34 & 17.12 & 18.05 & 20.56 \\
\hline
\end{tabular}

Vitamin/Mineral premix from Bio-organics supplied per kg: Vit. A, 10,000 iu; Vit. B, 2,000 iu; Vit. E, 13,000 iu; Vit. K, 1,500mg; Vit. B 12, 10mg; Riboflavin, 5,000mg; Pyridoxine, 1,300mg; Thiamine, 1,300mg; Panthothenic Acid; 8,000mg; Nicotinic Acid, 28,000mg; Folic Acid, 500mg; Biotin, 40mg; Copper, $\quad 7,000 \mathrm{mg}$; Manganese, 48,000mg, Iron, 58,000mg; Zinc, 58,000mg; Selenium, 120mg; Iodine, 60mg; Cobalt, 300mg; Cho line, 275,000mg.

\section{Results and discussion}

The crude protein and fibre of the cereal offals are represented in Table 2 . The values recorded were similar to that of Aduku,
(1993). The crude protein and fibre composition of the cereal milling by products are within the nutrient requirement outlined for livestock by NRC, (1995) 
Growth performance and nutrient digestibility of weaner pigs fed cereal offals in diets

Crude protein and fibre composition of cereal offal

\begin{tabular}{lll}
\hline Parameter & Crude protein & Crude fibre \\
\hline Maize offal & 11.80 & 10.52 \\
Wheat offal & 12.00 & 10.56 \\
Sorghum offal & 12.56 & 9.23 \\
Millet offal & 11.10 & 7.50 \\
Rice bran & 13.20 & 11.50 \\
\hline
\end{tabular}

Growth performance of weaner pigs fed cereal milling by-products

Table 3 shows the effect of the cereal milling by-products on the growth performance of weaner pigs. Final body weight, average daily feed intake (ADFI), average daily gain (ADG) and feed conversion ratio (FCR) were significantly $(\mathrm{P}<0.05)$ influenced by experimental diets. ADWG, ADFI and final weight were significantly higher $(\mathrm{P}<0.05)$ for pigs fed T1, T2, T3 and T4 diets than those fed T5 diet. This could be due to the palatability and acceptability of this diets as demonstrated by high intake of the diet and high ADG. The result agreed with the findings of García-Valverde et al. (2008) and Mwesigwa et al. (2012) who fed byproducts of maize and that of wheat. The dietary fibre in T1, T2, T3 and T4 diets could have improved pig gut morphology, hence stimulating mucosa enzyme activity which eventually improves nutrient digestibility and growth olist et al. 2009). Pigs fed $\mathrm{T} 5$ diet had significantly $(\mathrm{P}<0.05)$ lower feed intake and growth rate. This could be attributed to low protein intake as a result of the non-starch polysaccharide content of the diet (Nyachoti et al. 2006).

Table 3: Growth Performance of weaner pigs fed cereal milling by-products

\begin{tabular}{llllllll}
\hline & \multicolumn{7}{c}{ Dietary treatments } \\
\cline { 2 - 8 } Parameter & $\mathrm{T} 1$ & $\mathrm{~T} 2$ & $\mathrm{~T} 3$ & $\mathrm{~T} 4$ & $\mathrm{~T} 5$ & $\mathrm{SEM}$ & P-value \\
\hline Initial body weight $(\mathrm{kg})$ & 8.56 & 8.77 & 8.69 & 8.69 & 8.76 & 0.23 & 0.06 \\
Final body weight $(\mathrm{kg})$ & $38.25^{\mathrm{a}}$ & $31.75^{\mathrm{a}}$ & $30.00^{\mathrm{ab}}$ & $32.75^{\mathrm{a}}$ & $21.00^{\mathrm{c}}$ & 1.70 & 0.03 \\
Average daily weight gain $(\mathrm{kg})$ & $0.44^{\mathrm{a}}$ & $0.41^{\mathrm{a}}$ & $0.37^{\mathrm{a}}$ & $0.42^{\mathrm{a}}$ & $0.21^{\mathrm{b}}$ & 0.03 & 0.01 \\
Average daily feed intake $(\mathrm{kg})$ & $1.42^{\mathrm{a}}$ & $1.47^{\mathrm{a}}$ & $1.42^{\mathrm{ab}}$ & $1.47^{\mathrm{a}}$ & $0.90^{\mathrm{c}}$ & 0.04 & 0.03 \\
Feed conversion ratio & $3.24^{\mathrm{b}}$ & $3.60^{\mathrm{b}}$ & $3.84^{\mathrm{b}}$ & $3.59^{\mathrm{b}}$ & $4.32^{\mathrm{a}}$ & 0.38 & 0.02 \\
\hline Mean on same row bearing different superscript differ significantly, SEM = Standard error mean
\end{tabular}

Nutrient digestibility of weaner pigs fed cereal milling by-products

Nutrient digestibility of the diets is presented in Table 4. DM, CF, CF, EE and ash digestibility were significantly higher $(\mathrm{P}<0.05)$ for pigs fed $\mathrm{T} 1, \mathrm{~T} 2, \mathrm{~T} 3$ and $\mathrm{T} 4$ diets than those fed T5 diet. Nutrients digestibility of pigs fed T5 diet was significantly lower $(p<0.05)$. Lower values of nutrient digestibility observed in T5 diet could be attributed to the decrease in the mean retention time of this diet in the gastro-intestinal tract (Bindelle et al., 2008) brought about by higher levels of fibre, compared with those in T1, T2, T3 and T4 diets. High dietary fibre depresses apparent digestibility of dry matter and nitrogen, decreases daily body weight and increase feed to gain ratio The higher fibre digestibility observed for pigs fed T1, T2, $\mathrm{T} 3$ and T4 diet could have resulted from fermentation of CF in the hind gut with the volatile fatty acids produced contributing to the net energy requirement of the pigs. Birkett (2005) reported VFAs contribute about 5-28\% of the energy required for maintenance in the growing pig resulting from fermentation of fibre in the gastrointestinal. Utilization of $\mathrm{CF}$ by nonruminants has been shown to vary considerably according to the fibre source (Freira et al., 2000; Galassi et al., 2004), degree of lignification, level of inclusion and the extent of processing (Amaefule et al., 2009). 
Wafar, Tarimbuka, Sini, Adi, Lamalang and Bako

Table 4: Nutrient digestibility of weaner pigs fed cereal milling by -products in Diets

\begin{tabular}{llllllll}
\hline & \multicolumn{7}{c}{ Dietary treatments } \\
\cline { 2 - 7 } Parameter (\%) & T1 & T2 & T3 & T4 & T5 & SEM & P-value \\
\hline Dry matter digestibility & $86.42^{\mathrm{a}}$ & $82.57^{\mathrm{a}}$ & $81.50^{\mathrm{a}}$ & $80.94^{\mathrm{ab}}$ & $74.13^{\mathrm{c}}$ & 1.34 & 0.04 \\
Crude protein digestibility & $66.15^{\mathrm{a}}$ & $69.06^{\mathrm{a}}$ & $69.80^{\mathrm{a}}$ & $68.62^{\mathrm{a}}$ & $50.67^{\mathrm{b}}$ & 1.55 & 0.03 \\
Crude fibre digestibility & $72.94^{\mathrm{a}}$ & $73.42^{\mathrm{a}}$ & $69.38^{\mathrm{ab}}$ & $72.38^{\mathrm{a}}$ & $49.19^{\mathrm{a}}$ & 1.97 & 0.01 \\
Ether extracts digestibility & $73.93^{\mathrm{a}}$ & $72.17^{\mathrm{a}}$ & $70.73^{\mathrm{a}}$ & $70.81^{\mathrm{a}}$ & $52.13^{\mathrm{b}}$ & 2.64 & 0.02 \\
Ash digestibility & $60.56^{\mathrm{a}}$ & $62.53^{\mathrm{a}}$ & $69.39^{\mathrm{a}}$ & $59.67^{\mathrm{ab}}$ & $50.53^{\mathrm{c}}$ & 1.09 & 0.05 \\
\hline
\end{tabular}

Mean on same row bearing different superscript differ significantly

$\mathrm{SEM}=$ Standard error mean

\section{Conclusion}

The study reveals the using maize offal, sorghum offal, wheat offal and millet offal in the diet of weaned pigs improves their growth and nutrient digestibility, compared to rice bran. It is therefore recommended that pig farmers, animal nutritionist and feed milling industries should include maize offal, sorghum offal, wheat offal and millet offal in the diet of weaner pigs.

\section{References}

Adebayo, A. A. 1999. Climate II. In: Adamawa State in Maps. Edit; (A. A. Adebayo and A. L. Tukur). Paracleate publishers, Yola, Nigeria Nigeria. Pp 58.

Amaefule, K. U., Abasiekong, S. F., Ibe, S. N. and Onwudike, O. C. 2009. Digestibility and nutrient utilization of some agro-industrial by-products fed to growing pigs in the humid tropics. Pakistan Journal of Nutrition 8, 355-360

Bindelle, J., Leterme, $P$. and Buldgen, $A$. 2008 . Nutritional and environmental consequences of dietary fibre in pig nutrition: a review. Biotechnology Agronomy Social Environment 12, 69-80

De Lange, C. F. M., Pluske, J. R., Gong, J. and Nyachoti, C. M. 2010. Strategic use of feed ingredients and feed additives to stimulate gut health and development in young pigs. Livestock Science 134, 124-134.
De la Llata, M., Dritz, S. S., Tokach, M. D., Goddband, R. D., Nelssen, J. L. and Loughin, T. M. 2001. Effect of dietary fat on growth performance and carcass characteristics of growingfinishing pigsreared in a commercial environment. Journal of Animal Science 79, 2643-2650

Freira, J. P. B., Guerreiro, A. J. G., Cunha, L. F. and Aumaitre, A. 2000. Effect of dietary fibre source on total tract digestibility, caecum volatile fatty acids and digestive transit time in the weaned piglet. Animal Feed Science and Technology 87, 71-83

Galassi, G., Crovetto, G.M., Rapetti, L. and Tamburini, A. 2004. Energy and nitrogen balance in heavy pigs fed different fibre sources. Livestock Production Science 85, 253-262

García-Valverde, R., Barea, R., Lara, L., Nieto, R. And Aguilera, J. F. 2008. The effects of feeding level upon protein and fat deposition in Iberian heavy pigs. Livestock Science 114, 263-273

Kim, J. C., Mullan, B. P., Nicholls, R. R. and Pluske, J. R. 2011. Effect of Australian sweet lupin (Lupinus angustifolius L.) inclusion levels and enzyme supplementation on the performance and meat quality of grower/finisher pigs. Animal Production Science 51, 37-43 
Molist, F., Gomez de Segura, A., Gasa,J., Hermes, R.G., Manzanilla, E.G., Anguita, M. and Perez, J.F. 2009. Effects of the insoluble and soluble dietary fibre on the physiochemical properties of digesta and microbial activity in early weaned piglets. Animal Feed Science and Technology 149, 346-353.

Mwesigwa, R., Mutetikk, D. and Kugonza，D . R. 2012 . Performance of growing pigs fed diets based on by-products of maize and wheat processing. Tropical Animal Health and Production 43(3) 1-10

Nelson, F. S., Ameleke, G. Y., Donkoh, A. and Lamptey, V. 2007. Use of locally available agro-industrial by-products (AIBPs) for egg production in the Western Region of Ghana. The results of an on farm trial. Proceedings Ghana Society Animal Production Symposium, 15, 103-107
Nyachoti, C. M., Omogbenigun, F. O., Rademacher, M. And Blank, G. 2006. Performance responses and indicators of gastrointestinal health in early-weaned pigs fed lowprotein amino acid supplemented diets. Journal of Animal Science 84, 125-134.

SAS, 2003. SAS User's Guide: Statistics. SAS Inst., Inc., Cary, NC, USA

Uddin, O. and Osasogie, D. I. 2016. Constraints of Pig Production in Nigeria: A Case Study of Edo Central Agricultural Zone of Edo State. Asian Research Journal of Agriculture 2(4): 1-7

Wenk, C. 2001. The role of dietary fibre in the digestive physiology of the pig. Animal Feed Science and Technology 90, 21-33

Received: $20^{\text {th }}$ May, 2020

Accepted: $19^{\text {th }}$ December, 2020 